\title{
Short Communication: Salivary Secretion During Meals in Lactating Dairy Cattle
}

\author{
K. A. Beauchemin, ${ }^{\star 1}$ L. Eriksen, $\dagger$ P. Nørgaard, $\dagger$ and L. M. Rode ${ }^{\star 2,3}$ \\ *Agriculture and Agri-Food Canada, Lethbridge Research Centre, Lethbridge, Alberta, Canada T1J 4B1 \\ †Department of Basic Animal and Veterinary Sciences, Faculty of Life Sciences, University of Copenhagen, Frederiksberg, Denmark
}

\begin{abstract}
Four multiparous Holstein cows in midlactation were used in a $4 \times 4$ Latin square to evaluate whether source of forage influenced salivary secretion during eating in lactating dairy cows. The forages were allocated separately from the pelleted concentrates. Cows were offered 1 of 4 forages each period: barley silage, alfalfa silage, long-stemmed alfalfa hay, or chopped barley straw. Saliva secretion was measured during the morning meal by collecting masticates through the rumen cannula at the cardia of each cow. Rate of salivation ( $213 \mathrm{~g} / \mathrm{min}$ ) was not affected by forage source. However, the forage sources differed in eating rate ( $\mathrm{g}$ of $\mathrm{DM} / \mathrm{min}$ ), which led to differences in ensalivation of forages ( $g$ of saliva/g of DM and $g$ of saliva/g of NDF). On the basis of DM, ensalivation ( $\mathrm{g}$ of saliva/g of DM) was greatest for straw (7.23) and similar for barley silage, alfalfa silage, and alfalfa hay $(4.15,3.40$, and $4.34 \mathrm{~g} / \mathrm{g}$ of DM, respectively). Higher ensalivation of straw could be accounted for by its higher neutral detergent fiber (NDF) content; ensalivation of NDF (g of saliva/g of NDF) was actually greatest for long-stemmed alfalfa hay (12.4) and similar for the other chopped forages (8.9). Cows consumed concentrate about 3 to 12 times faster than the various forages (DM basis), and ensalivation of concentrate was much lower (1.12 $\mathrm{g}$ of saliva/g of DM) than for forages. Feed characteristics such as particle size, $\mathrm{DM}$, and NDF content affect salivary output during eating by affecting the eating rate. Slower eating rate and greater time spent eating may help prevent ruminal acidosis by increasing the total daily salivary secretion in dairy cows.
\end{abstract}

Received September 26, 2007.

Accepted January 3, 2008.

${ }^{1}$ Corresponding author: beauchemink@agr.gc.ca

${ }^{2}$ Present address: 3302 Beauvais Place, Lethbridge, Alberta, Canada T1K 3J5.

${ }^{3}$ Contribution number: LRC38707049. The contributions of B. Farr (Agriculture and Agri-Food Canada) in planning and executing this study are acknowledged. This project was funded by Agriculture and Agri-Food Canada.
Key words: dairy cow, salivation, eating behavior, chewing

Feed formulation models such as the Cornell Net Carbohydrate and Protein System and CPM-Dairy incorporate the concept of physically effective fiber to account for the effects of particle size and the intrinsic properties of fiber on chewing (Mertens, 1997). These models predict rumen $\mathrm{pH}$ from physically effective fiber intake, and implicit in these predictions is the assumption that physically effective fiber promotes chewing, and chewing promotes salivation, which elevates rumen $\mathrm{pH}$. The negative consequences of ruminal acidosis and the need to develop better predictions of rumen $\mathrm{pH}$ are well recognized (Krause and Oetzel, 2006). However, models of rumen pH (e.g., Argyle and Baldwin, 1988; Allen, 1997) are limited by the lack of information on salivary secretion in dairy cows fed a range of diets.

Only a few studies have measured the amount of saliva secreted during eating in lactating dairy cows and estimates range from 166 to $253 \mathrm{~g} / \mathrm{min}$ (Bailey, 1961; Cassida and Stokes, 1986; Maekawa et al., 2002b; Beauchemin et al., 2003; Bowman et al., 2003). Variability in estimated salivary secretion during eating among studies may be due in part to animal variation (Maekawa et al., 2002a) and feed characteristics (Bailey, 1961). Although forages vary in physically effective fiber content and the extent to which they promote chewing, their effects on saliva secretion in lactating dairy cows have not been quantified. The objectives of this study were to determine whether rate of salivation during eating differs for different feeds.

The experiment was conducted at the Dairy Facility of the Lethbridge Research Centre with approval of the Institutional Animal Care Committee and according to the Canadian Council on Animal Care Guidelines (Ottawa, Ontario, Canada). Four ruminally fistulated multiparous Holstein cows in late lactation (average BW, $635 \mathrm{~kg}$ ) were used in an experiment designed as a $4 \times 4$ Latin square. Each period consisted of $26 \mathrm{~d}$, with $14 \mathrm{~d}$ of adaptation followed by $12 \mathrm{~d}$ of measurements. The cows were housed in individual stalls and milked twice daily (average yield, $20 \mathrm{~kg} / \mathrm{d}, 4.0 \%$ fat). 
Table 1. Ingredient composition of the diets (\% DM basis)

\begin{tabular}{lcccc}
\hline Ingredient & $\begin{array}{c}\text { Barley } \\
\text { silage }\end{array}$ & $\begin{array}{c}\text { Alfalfa } \\
\text { silage }\end{array}$ & $\begin{array}{c}\text { Alfalfa } \\
\text { hay }\end{array}$ & $\begin{array}{c}\text { Barley } \\
\text { straw }\end{array}$ \\
\hline Barley silage & 51.30 & - & - & - \\
Alfalfa silage & - & 52.65 & - & - \\
Alfalfa hay & - & - & 51.73 & - \\
Barley straw & - & - & - & 15.86 \\
Molasses & - & - & - & 2.97 \\
Beet pulp & 32.89 & 34.39 & 43.52 & 61.24 \\
Soybean meal & 13.60 & 11.81 & 3.30 & 18.48 \\
Dicalcium phosphate & 1.57 & 0.60 & 0.90 & 1.10 \\
Sodium phosphate & 0.10 & - & - & - \\
Calcium carbonate & 0.50 & - & - & - \\
Urea & - & 0.50 & 0.50 & 0.30 \\
Mineral/vitamin premix & 0.05 & 0.05 & 0.05 & 0.05 \\
\hline
\end{tabular}

${ }^{1}$ Molasses was added to the straw.

The forage and concentrate components of the ration were allocated separately. Each period, the cows received 1 of 4 forages: barley silage, alfalfa silage, longstemmed alfalfa hay, or chopped barley straw. Each of the forages was paired with a concentrate so that the diet supplied sufficient $\mathrm{NE}_{\mathrm{L}}$ and metabolizable protein for cows producing $25 \mathrm{~kg}$ of milk (NRC, 1989). Thus, the amount of concentrate offered differed among diets. The concentrates were pelleted and consisted mainly of beet pulp. Diet composition is given in Table 1, with the characteristics of forages given in Table 2.

The concentrates were fed 3 times daily in restricted quantities at 0630,1200 , and $1530 \mathrm{~h}$ to ensure the desired forage-to-concentrate ratio was achieved. The forages were offered for ad libitum intake twice daily at 0700 and $1600 \mathrm{~h}$. Feeds were sampled daily and composited weekly for silages and monthly for hay, straw, and concentrates. The composited samples of silages were dried in a forced air oven at $55^{\circ} \mathrm{C}$ for $48 \mathrm{~h}$ to determine $\mathrm{DM}$ content.

On d 15 to 18 of each period, eating activities were monitored during the morning allocations of forage or concentrate. There were $2 \mathrm{~d}$ of measurements for each feed and cow. Because forage and concentrates were allocated separately, meals of each feed were monitored on separate days. A feeder was positioned in front of each cow, with the feeder placed on an electronic balance to record the weight. A trained observer recorded the time and weight of the feed in the feed bunk at the start and end of the morning meal to calculate meal duration and total intake per meal. A meal was said to start when the animal began to ingest the feed offered, and the meal was said to end once the animal made no further move to ingest feed for at least $5 \mathrm{~min}$. For concentrates, eating rate was determined as the total intake divided by the meal duration because meals were relatively short. However, for forages, the eating rate was calculated at intervals throughout the meal. This was done by recording the time and the weight of the feed remaining in the feed bunk each time the cow lifted her head from the feeder, permitting a stable reading to be made. The time that the cow lifted her head to chew and swallow was used as the end of one interval and the start of the next; thus, there were no time gaps within meals. The eating rate for forages was calculated at each interval throughout the meal as the quantity of forage consumed divided by the duration. The mean eating rate was then calculated by averaging the eating rates determined throughout the meal.

On d 19 to 26 of each period, salivary secretion during meals was measured. Swallowed boluses of ingested forage or concentrate were collected during the morning meal for each cow on 4 nonconsecutive days, with $2 \mathrm{~d}$ of collection for each feed type. Collections were made through the rumen cannula at the cardia after some of the rumen contents were removed to expose this region. The collections were made using a plastic bag sewn to a wire-hoop, similar to that used by Cassida and Stokes (1986). Tactile stimulation was avoided by minimizing contact with the rumen wall and the area around the cardia. The entire amount of concentrate consumed was collected because it was not possible to detect individual boluses. The forage boluses were collected for approximately 2 min at 5-min intervals throughout the meal. The rumen contents, which had been previously removed, as well as masticate that had been collected the previous day (refrigerated and then rewarmed), were placed into the rumen at the end of the collections. The masticated feed was dried in a forced-air oven at $55^{\circ} \mathrm{C}$ for $48 \mathrm{~h}$ to determine DM content.

The amount of saliva added to feed (ensalivation rate, $\mathrm{g} / \mathrm{g}$ of DM) was calculated as the difference in moisture content between the feed and the masticates. The ensalivation rate was expressed on the basis of fiber $(\mathrm{g} / \mathrm{g}$ of NDF) by correcting for the NDF content of the feed. Ensalivation of concentrate was calculated for the entire masticate, whereas ensalivation of forage was calculated for each 2-min collection and averaged over all collections within the meal for each animal. Salivation rate (g/min) was calculated for each collection by dividing the quantity of saliva by the duration of the collection period. The values were averaged over the meal within animal and day to calculate the amount of saliva secreted per minute during the consumption of forage.

The dried feeds were ground (1-mm screen, Wiley mill, Arthur Hill Thomas Co., Philadelphia, PA), and chemical analyses were performed in duplicate. The $\mathrm{DM}$ was determined by drying the samples at $135^{\circ} \mathrm{C}$ for $2 \mathrm{~h}$, followed by hot weighing (AOAC, 2005; method 930.15). The NDF was determined as described by Van Soest et al. (1991) using heat stable $\alpha$-amylase but without the use of sodium sulfite. The $\mathrm{ADF}$ was determined 
Table 2. Chemical and physical characteristics of forages

\begin{tabular}{lcccc}
\hline Item & $\begin{array}{c}\text { Barley } \\
\text { silage }\end{array}$ & $\begin{array}{c}\text { Alfalfa } \\
\text { silage }\end{array}$ & $\begin{array}{c}\text { Alfalfa } \\
\text { hay }\end{array}$ & $\begin{array}{c}\text { Barley } \\
\text { straw }\end{array}$ \\
\hline $\mathrm{DM}, \%$ & 32 & 38 & 86 & 88 \\
$\mathrm{NDF}, \%$ of DM & 46 & 40 & 35 & 80 \\
ADF, \% of DM & 28 & 34 & 27 & 49 \\
Mean particle size, ${ }^{1} \mathrm{~mm}$ & 4.3 & 4.2 & long & 86.7 \\
Cumulative DM passing the sieve, ${ }^{2} \%$ & & & \\
13.20 (37.34), mm & 95.21 & 91.17 & & \\
6.70 (18.95), mm & 87.76 & 81.95 & & \\
$4.75(13.44), \mathrm{mm}$ & 80.14 & 75.45 & & \\
$3.35(9.48), \mathrm{mm}$ & 59.41 & 62.82 & & \\
$1.18(3.34), \mathrm{mm}$ & 40.02 & 38.26 & & \\
$0.15(0.42), \mathrm{mm}$ & 2.76 & 4.37 & & \\
\hline
\end{tabular}

${ }^{1}$ Fifty percent of the weight of forage particles would be longer or shorter than this length.

${ }^{2}$ Given in parentheses is the maximum length $(\mathrm{mm})$ of particles passing the sieves calculated as $2 \sqrt{ } 2 \times$ sieve size (Beauchemin et al., 2003).

according to AOAC (2005; method 973.18). The particle distribution of the silages was measured as described by Beauchemin et al. (2003), with mean particle size calculated as the particle size for which $50 \%$ of the cumulative percentage weight of the sample was retained. Because a wet sieving technique was used, the loss of DM due to solubilization was accounted for in the calculations such that values reported are comparable with a dry sieving system. The mean particle size of the barley straw was estimated by manually measuring the length of individual particles.

The data for meals (duration, amount consumed, eating rate) and salivation were analyzed using a mixed-effects model in PROC MIXED (SAS Institute Inc., 2002). The model included the fixed effect of diet and the interaction between diet and day, and the random effects of cow and period. The 2 measurement days were considered a repeated effect with animal $\times$ period as the subject. The restricted maximum likelihood method was used for estimating the variance components and the Kenward-Roger's option was used to adjust the degrees of freedom. Treatment effects were examined using an LSD test when the main effect of diet was significant $(P<0.05)$. Three contrasts were used to compare silages (barley and alfalfa) to dry forages (hay and straw), to hay, and to straw.

Salivation rate $(213 \mathrm{~g} / \mathrm{min})$ during forage meals was not affected by source of forage, despite differences in moisture content, fiber content, and particle size (Table 3). Other studies have used the same cardial collection technique in dairy cows fed a range of diets and reported a mean salivation rate ranging from 166 to $253 \mathrm{~g} / \mathrm{min}$ (Bailey, 1961; Cassida and Stokes, 1986; Maekawa et al., 2002b; Beauchemin et al., 2003; Bowman et al., 2003). Some of the variability in salivary secretion during eating among studies may be due to genotype, stage of lactation, and parity of the cows (Maekawa et al., 2002a). But, within study, salivation rate was not systematically affected by feed characteristics.

Although forage type had no effect on salivation rate, the eating characteristics of meals depended upon the forage consumed (Table 4). On a fresh basis, silages were consumed 6 to 7 times faster than hay and straw; thus the dilution effect of moisture increased eating rate. However, the faster consumption of silages was not only due to moisture content because on a dry basis, silages were consumed about 2.5 times faster than hay and straw. This difference was not solely a reflection of fiber content, because on an NDF basis, silages were still consumed about twice as fast as hay and straw. The ability of cattle to eat silage NDF quicker than hay or straw NDF was likely due to the shorter particle size of the silages, although fragility of the fiber may also have been a factor (Iwaasa et al., 1996). Eating rate declines with increasing NDF concentration for long forages (Beauchemin, 1991). Chopping, as in the case of ensiled feeds, increases eating rate because the reduction in feed particle size before feeding reduces the need for subsequent mastication of the NDF by the cow (Beauchemin, 1991). The numerically faster eating rate of hay vs. straw was attributed to the higher fiber content of the straw because eating rates were similar for these feeds when expressed on the basis of NDF. Eating rate of all forages declined throughout the meal (data not shown).

The characteristics of forages (i.e., DM content, NDF content, and particle size) influenced the amount of saliva secreted during meals by affecting eating rate and duration of meals, rather than salivation rate (g/ min). A slower eating rate led to longer meals, and therefore, greater ensalivation of feed (g of saliva/g of DM) and more saliva secreted during the meal (Table 3). As such, about $80 \%$ more saliva was added to a gram of straw compared with the other forages, with 
Table 3. Salivation during a meal of concentrate or forage

\begin{tabular}{|c|c|c|c|c|c|c|c|c|c|}
\hline \multirow[b]{2}{*}{ Item } & \multirow{2}{*}{$\begin{array}{l}\text { Barley } \\
\text { silage }\end{array}$} & \multirow{2}{*}{$\begin{array}{l}\text { Alfalfa } \\
\text { silage }\end{array}$} & \multirow{2}{*}{$\begin{array}{c}\text { Alfalfa } \\
\text { hay }\end{array}$} & \multirow{2}{*}{$\begin{array}{l}\text { Barley } \\
\text { straw }\end{array}$} & \multirow[b]{2}{*}{$\mathrm{SE}$} & \multirow{2}{*}{$\begin{array}{l}\text { Effect } \\
\text { of diet }\end{array}$} & \multicolumn{3}{|c|}{ Contrast $^{1}$} \\
\hline & & & & & & & S vs. Dry & $\mathrm{S}$ vs. Hay & $\mathrm{S}$ vs. ST \\
\hline $\begin{array}{l}\text { Concentrate } \\
\mathrm{g} \text { of saliva/g of DM }\end{array}$ & 1.09 & 1.20 & 1.09 & 1.09 & 0.164 & 0.94 & 0.72 & 0.78 & 0.79 \\
\hline $\begin{array}{l}\text { Forage } \\
\mathrm{mL} \text { of saliva/g of } \mathrm{DM} \\
\mathrm{mL} \text { of saliva/g of } \mathrm{NDF} \\
\mathrm{g} \text { of saliva/min }\end{array}$ & $\begin{aligned} & 4.15^{\mathrm{b}} \\
& 9.03^{\mathrm{b}} \\
& 223.0\end{aligned}$ & $\begin{array}{r}3.40^{\mathrm{b}} \\
8.49^{\mathrm{b}} \\
191.4\end{array}$ & $\begin{array}{c}4.34^{\mathrm{b}} \\
12.39^{\mathrm{a}} \\
222.2\end{array}$ & $\begin{array}{r}7.23^{\mathrm{a}} \\
9.03^{\mathrm{b}} \\
213.9\end{array}$ & $\begin{array}{c}0.498 \\
0.936 \\
19.83\end{array}$ & $\begin{array}{c}<0.001 \\
0.02 \\
0.23\end{array}$ & $\begin{array}{l}0.01 \\
0.02 \\
0.11\end{array}$ & $\begin{array}{l}0.17 \\
0.003 \\
0.29\end{array}$ & $\begin{array}{c}<0.001 \\
0.73 \\
0.62\end{array}$ \\
\hline
\end{tabular}

${ }^{\mathrm{a}, \mathrm{b}}$ Means in a row with different superscript letters are significantly different $(P<0.05)$.

${ }^{1}$ Contrasts were: S vs. Dry, silage (barley silage and alfalfa silage) vs. dry forages (alfalfa hay and barley straw); S vs. Hay, silage (barley silage and alfalfa silage) vs. hay (alfalfa hay); S vs. ST, silage (barley silage and alfalfa silage) vs. barley straw.

no differences among the other forages. The greater ensalivation of straw compared with silage was partially attributed to its slower eating rate, caused in part by its high NDF content. When equalized for NDF content, straw was not more effective than the other forages in promoting salivation. In fact, ensalivation of NDF was greater for alfalfa hay than for the other forages. The higher ensalivation of alfalfa NDF may have been related to its longer particle length, even though the barley straw and silages were chopped coarsely.

The results from this study indicate that the main way that forage characteristics, such as physically effective fiber (which combines NDF content and particle size), affect salivary secretion during eating is through altering eating rate, which affects time spent eating. Thus, models that predict saliva output should account for differences in eating time among feeds, which reflect their physically effective fiber content.

Cows fed straw were offered a greater amount of concentrate per meal $(5.3 \pm 0.02 \mathrm{~kg}$ of $\mathrm{DM})$ than cows fed the other forages $(3.0 \pm 0.13 \mathrm{~kg}$ of DM) because of this diet's lower forage-to-concentrate ratio (Table 4). However, for cows on all diets, a small amount of concentrate frequently remained after the end of the meal. The eating rate during concentrate meals did not differ among concentrates (252 $\mathrm{g}$ of $\mathrm{DM} / \mathrm{min})$, so the longer duration of meals for cows on the straw diet simply reflected the greater consumption of concentrate.

Cows consumed the pelleted concentrate about 3 to 12 times faster than forage (DM basis) depending upon the source of forage. Similar eating rate for the various concentrates was expected because their composition varied only marginally. When particle size reduction of feed does not slow eating rate, salivation may be the limiting factor because feed may need a certain level of lubrication before swallowing (Carter and Grovum, 1990). In the present study the moisture content of the masticated concentrates varied from 50 to $60 \%$ compared with 80 to $90 \%$ for the forages. The slower eating rate of forages compared with concentrates appears to have been caused by the need to reduce particle size

Table 4. Eating characteristics during meals of concentrate or forage consumed by lactating dairy cows

\begin{tabular}{|c|c|c|c|c|c|c|c|c|c|}
\hline \multirow[b]{2}{*}{ Meal characteristics } & \multirow[b]{2}{*}{$\begin{array}{l}\text { Barley } \\
\text { silage }\end{array}$} & \multirow[b]{2}{*}{$\begin{array}{l}\text { Alfalfa } \\
\text { silage }\end{array}$} & \multirow[b]{2}{*}{$\begin{array}{c}\text { Alfalfa } \\
\text { hay }\end{array}$} & \multirow[b]{2}{*}{$\begin{array}{c}\text { Barley } \\
\text { straw }\end{array}$} & \multirow[b]{2}{*}{$\mathrm{SE}$} & \multirow[b]{2}{*}{$\begin{array}{l}\text { Effect } \\
\text { of diet }\end{array}$} & \multicolumn{3}{|c|}{ Contrast $^{1}$} \\
\hline & & & & & & & $\begin{array}{l}\text { S vs. } \\
\text { Dry }\end{array}$ & $\begin{array}{l}\text { S vs. } \\
\text { Hay }\end{array}$ & $\begin{array}{c}\text { S vs. } \\
\text { ST }\end{array}$ \\
\hline Total DMI, kg/d & 18.4 & 15.7 & 17.3 & 17.5 & 1.19 & 0.11 & 0.06 & 0.05 & 0.24 \\
\hline \multicolumn{10}{|l|}{ Concentrate } \\
\hline DMI, kg/meal & 3.08 & 2.62 & 2.75 & 4.06 & 0.362 & 0.06 & 0.26 & 0.83 & 0.02 \\
\hline Duration, $\mathrm{min} / \mathrm{meal}$ & $13.2^{\mathrm{b}}$ & $10.6^{\mathrm{b}}$ & $10.4^{\mathrm{b}}$ & $21.9^{\mathrm{a}}$ & 2.76 & 0.04 & 0.12 & 0.64 & 0.01 \\
\hline Eating rate, $g$ of $\mathrm{DM} / \mathrm{min}$ & 241.9 & 239.6 & 297.0 & 228.4 & 48.67 & 0.70 & 0.44 & 0.32 & 0.83 \\
\hline \multicolumn{10}{|l|}{ Forage } \\
\hline DMI, kg/meal & 1.02 & 0.78 & 1.44 & 0.77 & 0.284 & 0.28 & 0.38 & 0.12 & 0.74 \\
\hline Duration, $\min$ & $16.6^{\mathrm{b}}$ & $10.2^{\mathrm{b}}$ & $36.7^{\mathrm{a}}$ & $37.8^{\mathrm{a}}$ & 7.45 & 0.02 & 0.58 & 0.009 & 0.008 \\
\hline \multicolumn{10}{|l|}{ Eating rate, $\mathrm{g} / \mathrm{min}$} \\
\hline As fed & $209.5^{\mathrm{a}}$ & $248.5^{\mathrm{a}}$ & $43.0^{\mathrm{b}}$ & $24.6^{\mathrm{b}}$ & 55.90 & 0.02 & 0.004 & 0.01 & 0.007 \\
\hline DM & 67.0 & 94.4 & 41.1 & 21.6 & 20.36 & 0.08 & 0.02 & 0.11 & 0.026 \\
\hline $\mathrm{NDF}$ & 33.3 & 38.9 & 16.8 & 16.3 & 9.06 & 0.13 & 0.03 & 0.07 & 0.05 \\
\hline
\end{tabular}

${ }^{\mathrm{a}, \mathrm{b}}$ Means in a row with different superscript letters are significantly different $(P<0.05)$.

${ }^{1}$ Contrasts were: S vs. Dry, silage (barley silage and alfalfa silage) vs. dry forages (alfalfa hay and barley straw); S vs. Hay, silage (barley silage and alfalfa silage) vs. hay (alfalfa hay); S vs. ST, silage (barley silage and alfalfa silage) vs. barley straw. 
rather than lubricate feed because the lower DM content of the concentrate masticates indicates that cows are able to swallow less well lubricated feed.

An estimated 3 to $5.5 \mathrm{~L}$ of saliva was secreted during concentrate meals and from 5 to $13.5 \mathrm{~L}$ during forage meals. The larger estimates reflect the longer eating time for cows fed straw, whereas the smaller estimates reflect the shorter eating time of cows fed alfalfa silage. This study did not measure the number of meals consumed per day; therefore, it cannot be inferred that greater salivary secretion during meals corresponded to greater salivary secretion per day.

For dairy cows, salivation during eating appears to be about 1.3- to 2-times higher than resting salivation, based on the resting salivation rates reported by others (107 mL/min by Maekawa et al., 2002b; $138 \mathrm{~mL} / \mathrm{min}$ by Bowman et al., 2003; $151 \mathrm{~mL} / \mathrm{min}$ by Cassida and Stokes, 1986), whereas a 2- to 3-fold difference has been reported for beef cattle (Yarns et al., 1965). Thus, increasing the daily time spent eating either through increased meal frequency or by longer meals (by reducing the rate of intake during meals) would be beneficial in terms of increasing total salivary secretion and preventing ruminal acidosis. Increased salivation due to eating may be particularly beneficial in the period after calving. Cassida and Stokes (1986) observed that resting salivation rate was lower after calving than later in lactation, and Penner et al. (2007) reported that incidence and severity of ruminal acidosis increases immediately postpartum.

In conclusion, cows consumed concentrate about 3 to 12 times faster than the various forages offered. Ensalivation of concentrate was much lower (1.12 g of saliva/ $\mathrm{g}$ of DM) than for forages (3.40 to $7.23 \mathrm{~g}$ of saliva/g of DM). For forages, characteristics such as particle size, $\mathrm{DM}$, and NDF content affect salivary output during eating, mainly by affecting the eating rate and the time spent eating. Feeding forages that are consumed more slowly may help prevent ruminal acidosis by increasing the total daily salivary secretion.

\section{REFERENCES}

Allen, M. S. 1997. Relationship between fermentation acid production in the rumen and the requirement for physically effective fiber. J. Dairy Sci. 80:1447-1462.
AOAC. 2005. Official Methods of Analysis. Vol. I, 18th ed. Assoc. Off. Anal. Chem., Arlington, VA.

Argyle, J. L., and R. L. Baldwin. 1988. Modelling of rumen water kinetics and effects of rumen $\mathrm{pH}$ changes. J. Dairy Sci. $71: 1178-1188$.

Bailey, C. B. 1961. Saliva secretion and its relation to feeding in cattle. 3 . The rate of secretion of mixed saliva in the cow during eating, with an estimate of the magnitude of the total daily secretion of mixed saliva. Br. J. Nutr. 15:443-451.

Beauchemin, K. A. 1991. Ingestion and mastication of feed by dairy cattle. Pages 439-463 in The Veterinary Clinics of North America: Dairy Nutrition Management. C. J. Sniffen and T. H. Herdt, ed. W.D. Saunders Co., Philadelphia, PA.

Beauchemin, K. A., W. Z. Yang, and L. M. Rode. 2003. Effects of particle size of alfalfa-based dairy cow diets on chewing activity, ruminal fermentation, and milk production. J. Dairy Sci. 86:630-643.

Bowman, G. R., K. A. Beauchemin, and J. A. Shelford. 2003. Fibrolytic enzymes and parity effects on feeding behavior, salivation, and ruminal pH of lactating dairy cows. J. Dairy Sci. 86:565-575.

Carter, R. R., and W. L. Grovum. 1990. A review of the physiological significance of hypotonic body fluids on feed intake and ruminal function: Salivation, motility and microbes. J. Anim. Sci. 68:2811-2832.

Cassida, K. A., and M. R. Stokes. 1986. Eating and resting salivation in early lactation dairy cows. J. Dairy Sci. 69:1282-1292.

Iwaasa, A. D., K. A. Beauchemin, J. G. Buchanan-Smith, and S. N. Acharya. 1996. Effect of stage of maturity and growth cycle on shearing force and cell wall chemical constituents of alfalfa stems. Can. J. Anim. Sci. 76:321-328.

Krause, M. K., and G. R. Oetzel. 2006. Understanding and preventing subacute ruminal acidosis in dairy herds: A review. Anim. Feed Sci. Technol. 126:215-236.

Maekawa, M., K. A. Beauchemin, and D. A. Christensen. 2002a. Chewing activity, saliva production, and ruminal $\mathrm{pH}$ of primiparous and multiparous lactating dairy cows. J. Dairy Sci. 85:1176-1182.

Maekawa, M., K. A. Beauchemin, and D. A. Christensen. 2002b. Effect of concentrate level and feeding management on chewing activities, saliva production, and ruminal $\mathrm{pH}$ of lactating dairy cows. J. Dairy Sci. 85:1165-1175.

Mertens, D. R. 1997. Creating a system for meeting the fiber requirements of dairy cows. J. Dairy Sci. 80:1463-1481.

National Research Council. 1989. Nutrient Requirements of Dairy Cattle, 6th rev. ed. Natl. Acad. Sci., Washington, DC.

Penner, G. B., K. A. Beauchemin, and T. Mutsvangwa. 2007. Severity of ruminal acidosis in primiparous Holstein cows during the periparturient period. J. Dairy Sci. 90:365-375.

SAS Inst. Inc. 2002. SAS User's Guide: Statistics, Version 9.1. SAS Inst. Inc., Cary, NC.

Van Soest, P. J., J. B. Robertson, and B. A. Lewis. 1991. Methods for dietary fibre, neutral detergent fibre, and nonstarch polysaccharides in relation to animal nutrition. J. Dairy Sci. 74:35833597.

Yarns, D. A., P. A. Putnam, and E. C. Leffel. 1965. Daily salivary secretion by beef steers. J. Anim. Sci. 24:173-176. 